\title{
Protein Synthesis Inhibitors Block High-temperature Acclimation in Bell Pepper Leaves
}

\author{
X. Liu, J.A. Anderson ${ }^{1}$, and N.O. Maness \\ Department of Horticulture and Landscape Architecture, Oklahoma State \\ University, Stillwater, OK 74078
}

\section{B. Martin}

Department of Agronomy, Oklahoma State University, Stillwater, OK 74078

Additional index words. Capsicum annuum, heat shock

\begin{abstract}
Pepper (Capsicum annuum L. 'Early Calwonder') leaf disks were vacuuminfiltrated in distilled water (control), anisomycin, aurintricarboxylic acid, cycloheximide, ethionine, norvanine, or puromycin to determine whether protein synthesis inhibitors blocked high-temperature acclimation. After infiltration, one-half of the leaf disks were placed in an incubator at $24 \mathrm{C}$ as a control, and the other half were kept in a water bath at $38 \mathrm{C}$ for $2 \mathrm{~h}$ to induce acclimation. Test tubes containing the disks then were placed in a water bath at $50.5 \mathrm{C}$ for $0,1,5,10,15,25,35$, or 50 minutes. Thermotolerance was evaluated using electrolyte leakage. High-temperature acclimation was blocked in all six protein synthesis-inhibitor treatments. Only control disks infiltrated with distilled water acclimated. It seems that protein synthesis is required for high-temperature acclimation in bell pepper leaves.
\end{abstract}

Certain plants acclimate to high temperatures following pretreatments at sublethal high temperatures (Lester, 1986). Heat pretreatments can induce synthesis of heat-shock proteins (HSP) (Cooper and Ho, 1983). Shifting desert succulents from 30C day/20C night to 50C day/40C night resulted in accumulation of two low-molecular-weight proteins and increased heat tolerance by 6 to $8 \mathrm{C}$ (Kee and Nobel, 1986). Although not all plant cells require HSP synthesis to acclimate to high temperature (Xiao and Mascarenhas, 1985), the correlation between HSP synthesis and acclimation to high temperatures suggests that HSP may provide a basis for plants to withstand a normally lethal high temperature.

Protein synthesis generally occurs through four stages: 1) amino acid activation, 2) initiation of the polypeptide chain, 3) elongation, and 4) termination of translation (Stryer, 1988). It can be repressed by various inhibitors acting at different stages of synthesis. Pretreatment with protein synthesis inhibitors is expected to modify HSP metabolism and high-temperature acclimation by blocking HSP synthesis. Pretreatment of Dictyostelium (Loomis and Wheeler, 1980) and mammalian cells (Henle and Leeper, 1982) with cycloheximide blocked HSP synthesis and prevented increased thermotolerance. Widlitz et al. (1986), however, reported that inhibition of HSP synthesis by cycloheximide did not inhibit increased

Received for publication 13 July 1995 . Accepted for publication 6 Oct. 1995. Approved for publication by the director of the Oklahoma Agricultural Expt. Station. The cost of publishing this paper was defrayed in part by the payment of page charges. Under postal regulations, this paper therefore must be hereby marked advertisement solely to indicate this fact.

${ }^{1}$ To whom reprints should be addressed. thermotolerance in rat fibroblasts. Our objective was to determine whether protein synthesis inhibitors, acting at various stages in protein synthesis, blocked high-temperature acclimation in pepper leaf disks.

\section{Materials and Methods}

'Early Calwonder' pepper seeds were planted in 36-liter pots containing commercial potting soil (Fafard GP Mix, Springfield, Mass.) blended with micronutrients (Micromax, Sierra Chemical, Milpitas, Calif.) at 0.2 g.liter ${ }^{-1}$. Plants were monitored daily, with watering based on soil color and pot weight. Irrigation water contained $1 \mathrm{~g} 20 \mathrm{~N}-9 \mathrm{P}-17 \mathrm{~K}$ soluble fertilizer/liter. The growth chamber was maintained at $23 \mathrm{C}$ day/20C night cycles with a 14-h photoperiod. Photosynthetic photon flux of $500 \mu \mathrm{mol} \cdot \mathrm{m}^{-2} \cdot \mathrm{s}^{-1}$ at canopy height was supplied by fluorescent and incandescent bulbs.

Disks (14 $\mathrm{mm}$ in diameter) were cut with a cork borer from fully expanded, nonsenescent leaves 60 to 80 days after sowing seeds. Disks were rinsed with distilled water at least three times to remove the exogenous electrolytes. On each date, 336 leaf disks were divided randomly into seven groups to receive proteinsynthesis inhibitor treatments. Each group, containing 48 leaf disks, was vacuum-infiltrated in one of seven protein-synthesisinhibitor solutions [distilled water control; (in $\mu_{\mathrm{M}}$ ) anisomycin (500), aurintricarboxylic acid (100), cycloheximide (1), ethionine (500), norvanine (1000), and puromycin (10)]. All inhibitors were dissolved in distilled water, except aurintricarboxylic acid, which was first dissolved in $10 \%$ ethanol (by volume) before dilution with distilled water to a final ethanol concentration of $1 \%$ by volume. Concentra- tions of each inhibitor that were effective in blocking acclimation, without toxic effects based on electrolyte leakage, were determined in preliminary experiments (data not presented). Disks were held at $24 \mathrm{C}$ for $30 \mathrm{~min}$ in the inhibitor solutions after infiltration to ensure uptake. Leaf disks then were transferred to test tubes containing $0.5 \mathrm{ml}$ of distilled water to prevent secondary water stress. Onehalf of the tubes, containing one leaf disk each, were placed in an incubator at $24 \pm 0.2 \mathrm{C}$ as a control, and the other half were kept in a water bath at $38 \pm 0.1 \mathrm{C}$ for $2 \mathrm{~h}$ to induce acclimation.

Tubes then were placed in a water bath at $50.5 \pm 0.1 \mathrm{C}$ for $0,1,5,10,15,25,35$, or $50 \mathrm{~min}$. Separate groups of three subsamples for each inhibitor-acclimation treatment combination were removed at each exposure interval. Thermotolerance of treated, pepper leaf disks was evaluated using electrolyte leakage (Anderson et al., 1990). The experiment, which was conducted on four dates, was a 2 (acclimation treatments) $\times 7$ (inhibitors) $\times 8$ (exposure times) factorial treatment arrangement with dates used as blocks in a randomized complete-block design. The data were analyzed using the general linear models procedure (SAS Institute, Cary, N.C.). After significant treatment effects were noted, trend analysis was conducted, and linear, quadratic, and cubic regression coefficients for exposure time vs. electrolyte leakage were calculated. Critical exposure time, Tmid (the duration at $50.5 \mathrm{C}$ that resulted in an electrolyte leakage value equal to the sum of maximum and minimum electrolyte leakage divided by two), then was determined from fitted curves. Tmid values were calculated for each of the four dates the experiment was conducted. Tmid means were separated within acclimation treatment by Duncan's new multiple range test at $P \leq 0.05$.

\section{Results and Discussion}

High-temperature acclimation was blocked in all six protein-synthesis-inhibitor treatments (Table 1), and, therefore, only control disks infiltrated with distilled water acclimated. Significant differences in Tmid were absent among the disks kept at 24C. All inhibitors elicited a Tmid significantly shorter than disks infiltrated with distilled water before exposure to $38 \mathrm{C}$.

Table 1. Critical exposure times (Tmid, min) for pepper leaf disks infiltrated with water or protein synthesis inhibitors before acclimation pretreatments at 24 or $38 \mathrm{C}$ for $2 \mathrm{~h}$.

\begin{tabular}{lrr}
\hline \hline & \multicolumn{2}{c}{$\begin{array}{c}\text { Pretreatment } \\
\text { temp }\left({ }^{\circ} \mathrm{C}\right)\end{array}$} \\
\cline { 2 - 3 } Inhibitor & 24 & 38 \\
\hline Distilled water & $7.2 \mathrm{a}^{\mathrm{z}}$ & $27.2 \mathrm{a}$ \\
Anisomycin $(500 \mu \mathrm{M})$ & $7.5 \mathrm{a}$ & $7.9 \mathrm{~b}$ \\
Aurintricarboxylic acid $(100 \mu \mathrm{M})$ & $7.1 \mathrm{a}$ & $6.8 \mathrm{~b}$ \\
Cycloheximide $(1 \mu \mathrm{M})$ & $7.4 \mathrm{a}$ & $8.9 \mathrm{~b}$ \\
Ethionine $(500 \mu \mathrm{M})$ & $7.2 \mathrm{a}$ & $7.5 \mathrm{~b}$ \\
Norvanine $(1000 \mu \mathrm{M})$ & $6.7 \mathrm{a}$ & $7.5 \mathrm{~b}$ \\
Puromycin $(10 \mu \mathrm{M})$ & $6.3 \mathrm{a}$ & $7.3 \mathrm{~b}$ \\
\hline
\end{tabular}

${ }^{2}$ Mean separation within columns by Duncan's new multiple range test at $P \leq 0.05$. 
Cycloheximide is a glutarimide antibiotic that can inhibit initiation, elongation, and termination stages in protein synthesis (Vazquez, 1979). Puromycin acts by interrupting polypeptide-chain elongation due to structural similarity to aminoacyl-tRNA (Stryer, 1988). Aurintricarboxylic acid has been used widely to block protein synthesis initiation by interacting with small ribosome subunits (Marcus et al., 1970). Anisomycin suppresses protein synthesis by specifically blocking peptidebond formation and acting on the termination step (Grollman, 1967). Ethionine and norvanine act at the level of amino-acid activation (Vazquez, 1979). Although inhibitors acted on different protein synthesis stages, all prevented acclimation, and presumably, HSP synthesis was blocked. Also, inhibitors possibly acted indirectly by a mechanism not involving HSPs. Inhibitors could have affected membrane properties by changing fatty acid saturase-desaturase activity or by changes in membrane protein : sterol : phospholipid ratios.
This study does not provide direct evidence that HSPs were triggered in control disks exposed to $38 \mathrm{C}$ or that HSPs were not produced in the disks treated with protein-synthesis inhibitors. Protein synthesis apparently is required for high-temperature acclimation in bell pepper leaves. Further experiments must be conducted to determine whether HSP or other proteins are responsible for the acquisition of thermal tolerance in pepper leaves.

\section{Literature Cited}

Anderson, J., G. McCollum, and W. Roberts. 1990. High temperature acclimation in pepper leaves. HortScience 25:1272-1274.

Cooper, P. and T.H.D. Ho. 1983. Heat shock proteins in maize. Plant Physiol. 71:215-222.

Grollman, A.P. 1967. Mode of action of anisomycin. J. Biol. Chem. 242:3226-3233.

Henle, K.J. and D.B. Leeper. 1982. Modification of the heat response and thermotolerance by cycloheximide, hydroxyurea, and lucanthone in $\mathrm{CHO}$ cells. Radiation Res. 90:339-347.
Kee, S.C. and P.S. Nobel. 1986. Concomitant changes in high temperature tolerance and heat shock proteins in desert succulents. Plant Physiol. 80:596-598.

Lester, G.E. 1986. Physiology of melon leaf membrane thermostability during heat conditioning. J. Amer. Soc. Hort. Sci. 111:561-564.

Loomis, W.F. and S. Wheeler. 1980. Heat shock response of Dictyostelium. Dev. Biol. 79:399408.

Marcus, A., J.D. Bewley, and D.P. Weeks. 1970. Aurintricarboxylic acid and initiation factors of wheat embryo. Science 167:1735-1736.

Stryer, L. 1988. Biochemistry. 3rd ed. W.H. Freeman and Co., New York.

Vazquez, D. 1979. Inhibitors of protein biosynthesis. Springer-Verlag, Berlin.

Widlitz, R.B., B.E. Magun, and E.W. Gerner. 1986. Effects of cycloheximide on thermotolerance expression, heat shock protein synthesis and heat shock protein mRNA accumulation in rat fibroblasts. Mol. Cellular Biol. 6:1088-1094.

Xiao, C.M. and T.P. Mascarenhas. 1985. High temperature-induced thermotolerance in pollen tubes of Tradescantia and heat-shock proteins. Plant Physiol. 78:887-890. 